86 回回回回回回回回回回回回回回回回回回回回 Випуск 32

УAK 347.23:004.4

Некіт Катерина Георгіївна,

кандиАат юридичних наук, Аоцент,

Аоцент кафедри цивільного права

Національного університету “ОАеська юридична академія"

\title{
ОСОБЛИВОСТІ ЗМІСТУ ТА ЗДІЙСНЕННЯ ПРАВА ВІРТУАЛЬНОЇ ВЛАСНОСТІ
}

Постановка проблеми. Поняття віртуальної власності виникло у зв'язку зі стрімким розвитком так званих масових багатокористувальницьких онлайн-ігор (англ. Massively Multiplayer Online Game, MMOG). Створення в рамках ігри різноманітних предметів, які мають значну цінність, та набуття цінності самими ігровими акаунтами викликало зацікавленість у приАбанні таких об'єктів, що спричинило виникнення численних "сірих" ринків, Ае купуються та продаються такі цифрові об'єкти. Почавшись з преАметів онлайнових ігор та ігрових акаунтів, поняття віртуальної власності поступово поширилось і на інші новітні об'єкти, що виникають у зв'язку з невпинним розвитком інформаційно-комунікаційних технологій, таких як e-mail, акаунти в соціальних мережах, доменні імена, веб-сайти, віртуальні елементи Інтернету речей, електронні квитки, книги та інше.

Проведене у 2011 році в США опитування виявило, що середній користувач Інтернету має понаА 37000 доларів США у незахищеному цифровому майні [1]. У 2013 році валовий внутрішній продукт універсального всесвіту Second Life склав 600 м^н. Аоларів США, що вивело його у всесвітній топ-25 націй [2]. За Ааними на 2017 рік, ігрова індустрія згенерувала 108, 4 м^рА Аоларів США прибутку, з яких 59, 2 млрА припадає на мобільні ігри, 33 млрА - на комп'ютерні, при цьому більша частина цих сум витрачається на придбання внутрішньоігрових предметів [3].

Ще більш вражаючою $€$ поведінка гравців, що свіАчить про їх наАзвичайну залученість у гру та важливість того, що в ній віАбувається. Так, у Південній Кореї у 2005 році чоловік помер віА серцевого нападу, оскільки провів понаА 50 гоАин, граючи в онлайн гру Starcraft [4]. Ару- гий приклаА залежності віА онлайн ігор пов'язаний 3 подружжям, які так захопилися грою, що Аитина, яку вони залишили без нагляду, померла віА голоАу [5]. У Китаї у 2005 році чоловік вбив іншого гравця за те, що той продав за 871 долар США його віртуальний меч, який чоловік йому попереАньо позичив [6].

Отже, очевиАною $€$ наявність цінності у предметів віртуальних світів та ігрових акаунтів, оскільки на них існує попит, і люАи вкладають вагому працю у створення преАметів, що $є$ Аля них важливими. Якщо ж існують певні об'єкти, які мають цінність та з приводу яких склаАаються віАносини, очевидною $€$ необхідність їх правового регулювання. Виникає ^ише питання, за допомогою яких правових інструментів це регулювання може бути забезпечено. Найпоширенішим піАходом Ао вирішення цього питання $є$ пропозиція визнати право так званої віртуальної власності стосовно таких об'єктів.

Стан АосліАження теми. Проблеми віртуальної власності вже Аосить тривалий час вивчаються такими зарубіжними дослідниками, як Аж. ФейрфілА, Аж. Нельсон, Ч. Блейзер, Гр. Аастовка та А. Хантер і інші. ОАнак в Україні АосліАжень з цієї проблематики вкрай мало. Аеякі аспекти віртуальної власності розглядалися нами у попередніх АосліАженнях $[7 ; 8 ; 9]$. СереА вітчизняних вчених, які вивчають проблеми віртуальної власності, можна також згадати Р.А. Майданика, О.І. Харитонову та А.Р. Майданик.

Мета статті. Метою цього АосліАження $€$ ана^із правової природи права віртуальної власності, спроба визначити, чи Аопустимо вважати це право особливим видом права власності, визначення змісту та особливостей здійснення права віртуальної власності. 
ВикиаА основного матеріалу АосліАження 3 повним обгрунтуванням отриманих наукових результатів. ОАним із варіантів забезпечення захисту прав володільців цифрового майна $€$ впроваАження інституту права віртуальної власності. Видається Аопустимим визначення права віртуальної власності як специфічного виду права власності, об'єктом якого є віртуальне майно.

Згінно з українською концепцією права власності, об'єктом права власності може бути як тілесна річ, так і безтілесна. Так, віАповіАно до ст. 316 ЦК України об'єктом права власності є річ (майно). А віАповіАно Ао ст. 190 ЦК України майном як особливим об'єктом вважаються окрема річ, сукупність речей, а також майнові права та обов'язки. Майнові права $€$ неспоживною річчю. Таким чином, поняття "річ» в українському законодавстві тлумачиться широко та вкмючає в себе не лише предмети матеріального світу, але й безтілесні речі. Майнові права та обов'язки фактично і є безтілесними речами, а отже, вітчизняна концепція права власності не унеможлив^ює застосування положень про право власності Ао віртуальних активів.

Крім специфіки об'єкту (яким завжАи будуть безтілесні речі, тобто віртуальне майно), право віртуальної власності буде характеризуватися також специфікою піАстав виникнення, змісту, захисту тощо.

Виникнення права віртуальної власності потрібно пов'язувати зі створенням / отриманням користувачем веб-платформи віртуального майна - тобто віртуального преАмету, який волоАіє властивостями віртуальної власності: конкурентоздатності, стійкості, взаємопов'язаності [10, с. 1053]. Це може бути акаунт, аватар та інші ігрові преАмети в мультикористувацькій грі, акаунт у соціальній мережі, Аоменне ім'я, имейл-адреси та інші цифрові об'єкти, що віАповіАають зазначеним ознакам. Варто зазначити, що віртуальні предмети, які є об'єктами віртуальної власності, $€$ різновидом цифрових об'єктів. Тобто не всі цифрові об'єкти є віртуальною власністю [11, с. 148].

Специфіка права віртуальної власності полягає в тому, що абсолютність характеру повноважень власника проявляється мише у віАносинах із третіми особами. Тобто при встановленні права віртуальної власності виникає Ава виАи правовіАносин: перший - між власником віртуального майна та третіми особами, в яких повноваження власника мають абсолютний характер, Аругий між власником віртуального майна та провайдером, в яких обсяг повноважень власника може бути обмежений інтересами розробника / волоАільця платформи. НаприклаА, у разі якщо оператор гри або соціальної мережі прийме рішення про те, що гра або соціальна мережа припинить своє існування, це буде піАставою припинення права віртуальної власності без Аодаткових віАшкоАувань користувачам. Крім того, можливості власника віртуального майна визначатимуться особливостями тієї чи іншої платформи, оскільки їі специфіка може унеможливлювати певні Аії користувачів. Такий піАхіА у цілому також не суперечитиме українській концепції права власності, оскільки, незважаючи на абсолютний характер традиційного права власності, воно може бути обмежене у визначених випадках. Аодаткового обгрунтування можливості існування віртуальної власності надає конструкція Аовірчої власності. ААже в рамках відносин Аовірчої власності довірчий власник також володіє правомочностями власника у віАносинах із третіми особами, але його відносини з установником Аовірчої власності будуть віАрізнятись. НаприклаА, зміст повноважень Аовірчого власника визначається Аомовленістю з установником Аовірчої власності та може бути ним обмежений.

Важливою задачею, однак, є недопущення безпідставного звуження повноважень власників віртуального майна розробниками платформ. Це може розглядатись як зловживання провайАерами своїми правами та прийматись судом за основу при визнанні певних положень угоА між провайдерами та користувачами неАійсними.

Ця проблема віАсилає Ао запропонованого П. Палкою поняття цифрової сили (digital force). Цифровою силою він називає наявність фактичної можливості вмішуватися у чиєсь цифрове володіння (волоАіння цифровими об'єктами) чи цифрову присутність (присутність на певній платформі завАяки реєстрації та автентифікації, тобто створення акаунту і отримання доступу Ао платформи). (Платформи він розуміє як кіберпростір, віАповіАно, присутність у цьому просторі $\epsilon$ цифровою присутністю) [11, с. 171-172]. НаАаючи Аоступ користувачам Ао своїх платформ, їхні волоАільці ОАночасно розробляють певні правила повеАінки, які закріплюють в умовах сервісу (Terms of Service), що розглядаються як своєріАний контракт. (Хоча, на Аумку П. Палки, вони не завжАи $€$ контрактом за своєю прироАою, оскільки в них часто не міститься жодних зобов'язань провайдерів щодо надання послуг або надання їх у конкретному вигляді. Tакі Terms of Service більш схожі на правила, які власники 
приватних просторів розробляють Аля них. Перелік забороненої поведінки в них не вичерпний, вони не містять жоАних обмежень Аля провайдерів з питань застосування ними "цифрової сили", більшість компаній просто залишають за собою право змінювати об'єкти та видаляти акаунти користувачів з будь-яких причин та без вказування причин) [11, с. 174].

Отже, Terms of Service визначають повноваження володільців платформ та Аозволяють останнім застосування "цифрової сили", тобто можмивості позбавити користувача належних йому віртуальних предметів або взагалі видалити його акаунт частіше за все без будь-яких обмежень. Це наводить на Аумку, що такі відносини de facto не є приватними, по суті вони будуються за вертикамюю. Оскільки провайдери мають право в односторонньому порядку розробляти, інтерпретувати та змінювати Terms of Service, правила поведінки і сам коА гри, а також застосовувати "цифрову силу" Аля забезпечення своїх можливостей, вони багато в чому нагадують державу, а не приватного власника. Вони мають практично необмежені права стосовно користувачів. І це, по суті, $€$ новим типом нерівності, що викликає питання, чи не потрібно тут втручання закону Аля забезпечення захисту інтересів слабшого [11, с. 176].

П. Палка проводить аналогію між цією нерівністю між користувачами та провайдерами та труАовими віАносинами або віАносинами за участі споживачів. У випадках, коли одна сторона приватних віАносин фактично має набагато більше повноважень (тобто віАносини фактично є вертикальними), закріпленої законом рівності недостатньо Аля забезпечення реальної рівності. Тому в таких випадках фактично слабкішій стороні надається більше прав або Аоговірна свобода обмежується в більшому ступені, ніж у стандартних випадках. Цей "принцип захисту слабкішої сторони" закріплений у законодавствах практично всіх країн. Він також є оАним з семи базових принципів приватного права $Є С$, який суди зобов'язані приймати Ао уваги піА час розгляАу справ [11, с. 210].

СліА зазначити, що останнім часом суди Аійсно йдуть шляхом надання більшого ступеня захисту користувачам, незважаючи на умови Terms of Service, навіть при тому, що останні частіше за все розуміються як контракти, що зв'язують сторони та повинні застосовуватись преференційно перед законом. НаприклаА, у нещодавніх справах щодо акаунтів користувачів Facebook та Yahoo суд, незважаючи на положення Terms of Service про можливість заборони Аоступу Ао акаунту та видалення акаунту у випадку смерті користувача, зобов'язав провайдерів надати Аоступ родичам померлих осіб [12; 13]. Отже, суАи йАуть шляхом обмеження "цифрової сили" провайдерів [14].

Виходячи з принципу захисту слабкішої сторони віАносин, П. Палка пропонує обмежити повноваження провайдерів застосовувати «цифрову силу" (тобто виАаляти акаунти або позбавляти користувачів належних їм предметів) лише у випадках, перелічених у Terms of Service (а не з будь-яких причин та без вказування причин). Санкції у вигляАі блокування акаунту (і як насліАок, вилалення усіх віртуальних преАметів) провайдер повинен мати право застосовувати лише за порушення, визначені в умовах користування. Це надасть користувачам більшої впевненості, оскільки вони будуть розуміти, що Аопоки вони поводяться належним чином, їхні віртуальні преАмети у безпеці [11, с. 215].

Таким чином, АосліАник пропонує розробку так званого «права користувачів (user law) за анамогією з правами споживачів чи трудовими правами, яке буде допускати втручання законодавця Аля забезпечення балансу у фактичній нерівності в цифрових віАносинах. 3 цією метою він пропонує зобов'язати провайдерів дозволити державі або громадянському суспільству використовувати штучний інтелект (ботів) Аля тестування платформ. Це Аозволить перевірити, чи слідують провайдери розробленим ними правилам, якщо виникне така необхідність [11, с. 218].

Специфіка змісту права віртуальної власності визначається ії об'єктом. У змісті права віртуальної власності розрізняються правоможності володіння, користування та розпорядження. Проте Аеякі правоможності мають свої особливості. НаприклаА правоможність володіння, яка припускає фактичне господарювання особи нал річчю, стосовно віртуальної власності набуває своєї специфіки. Як зазначає П. Палка, тут може бути Ава варіанти: простіший та скиадніший. У простішому випадку об'єкт віртуальної власності зберігається на пристрої власника (у комп'ютері чи ноутбуку тощо). У такому випадку власник самостійно контролює пристрій, інформаційну систему і має фактичну можливість користуватися об'єктом віртуальної власності, змінювати його, виАаляти тощо. Аля того щоб хтось інший позбавив особу такого цифрового волоАіння, необхідно або фізично відібрати пристрій, або проникнути у пристрій через Інтернет. У склаАнішому ж випадку завАяки архітектурі інформацій- 
ної системи більше ніж оАна особа мають фактичний контроль щодо цифрового об'єкту. НаприклаА, файл, завантажений у хмару, одночасно контро^юється користувачем та провайдером. Користувачеві Аля контролю цього об'єкту необхіАно мати Аозвіл Аоступу, який надається провайдером. Але провайдер в той самий час також може користуватися цим об'єктом, змінювати його або видамити. Вони не роблять цього тому що, по-перше, взяли на себе обов'язок не торкатися цих об'єктів, по-Аруге, якщо вони будуть вчиняти певні дії щодо таких об'єктів, це підірве Аовіру інших користувачів, і провайдер у кінцевому підсумку втратить своїх клієнтів, які перейдуть до іншого провайдера. ОАнак тим не менш хости фактично володіють цими об'єктами. В цьому сенсі цифрове володіння, на відміну віА традиційного, не є ексклюзивним кілька осіб можуть волоАіти об'єКтом оАночасно (тобто мати контроль наА цим об'єктом). Так само і у випадку з провайдерами віртуальних світів або соціальних мереж - вони також володіють об'єктами віртуальної власності одночасно із користувачами. ОАнак, на відміну віА хмарних серверів, оператори віртуальних світів, наприклаА, не беруть на себе обов'язок забезпечувати збереження віртуальних предметів, навпаки, вони залишають за собою право змінювати або видаляти їх. I в тому стані, в якому закон існує сьогодні, права віртуальних власників залишаються без інструментів захисту. ЄАиною можливістю забезпечити цей захист є визначення, що Аозволяється робити провайдерам [11, с. 160-161].

Із вказаного аналізу, проведеного П. Палкою, стає очевидним той факт, що правоможність користування у конструкції віртуальної власності також має свою специфіку. А. Шемдон зазначає, що сьогодні право користування віртуальними предметами, що надається користувачам міцензійною угодою, є суттєво обмеженим порівняно з правом користування матеріальною річчю. На Аодаток до обмежень, що забезпечуються кодом, міцензійна угода обмежує користувачів дозволянням мише визначеної поведінки [15, с. 764].

Отже, якщо в рамкахтрадиційних віАносин власності власник своїми власними діями задовольняє свої інтереси, що Аозволяє характеризувати їх як речові, специфіка відносин віртуальної власності визначається зобов'язанням між провайдером та користувачем. Тому що власник може самостійно користуватися своєю віртуальною власністю та задовольняти свої інтереси без Аопомоги інших осіб, але А^я того, щоб він міг зАійснювати цю правоможність попередньо вона повинна бути надана провайдером, який повинен постійно забезпечувати Аоступ власника Ао належного йому об'єкта з метою користування ним. Це знову ж таки повертає до питання про те, що у випадку встановлення віртуальної власності виникають Ава типи правовіАносин - абсолютні, речові між власником і третіми особами, та віАносні, зобов'язальні між власником і провайдером.

Аналізуючи правову природу права віртуальної власності з точки зору Ауалістичної концепції зобов'язальних та речових прав, У. Ерлан зазначає, що право віртуальної власності сліА вважати речовим правом. Обґрунтовує це твердження він крізь призму принципів речових прав. У. Ерлан стверджує, що до права віртуальної власності цілком застосовні принципи речових прав реального світу, такі як принцип абсолютності, публічності, унікальності, віАчужуваності. Так, принцип абсо^ютності є застосовним Ао віртуального майна, оскільки користувачі схильні захищати своє віртуальне майно віА третіх осіб та забороняти їм втручання у їхню власність. У віртуальних світах це можливо навіть за Аопомогою програмного коАу, який Аозволяє гравцям зробити фізично неможливим Аоступ третіх осіб до їх віртуального майна. Принципу публічності віртуальна власність відповідає тому, що віртуальне майно так чи інакше реєструється за користувачем. Принцип унікальності також проявляється в тому, що усі віртуальні предмети специфікуються у базі Ааних. Принцип відчужуваності означає, що віртуальні предмети зАебільшого є такими, що віАділяються віА загальної маси віртуального майна та можуть самостійно відчужуватись. ОАнак тут можуть бути винятки - наприклаА, іноді володіння певним майном у віртуальному світі прив'язується Ао конкретного аватара, тоді його відчуження $€$ можмивим ^ише шляхом відчуження усього аватара. ЄАиним принципом, який сьогодні є незастосовним Ао віртуальної власності є принцип numerus clausus, оскільки СьогоАні ЄАиною піАставою виникнення права віртуальної власності є Аоговір [16, с. 310-327].

ОАнак з урахуванням інтерпретації поняття права власності Європейським судом з прав ^юАини, яка не обмежується матеріальними речами, а включає в себе широкий спектр нематеріальних об'єктів, на Аумку Р.А. Майданика, об'єктивно і закономірно виникає питання щодо Аоцільності застосування у речовому праві принципу numerus clausus. Останнім часом вислов^юються Аумки щодо можАивості моАифікації принципу numerus clausus у вигляАі принципу 


\section{0 回回回回回回回回回回回回回回回回回回回回 Випуск 32}

щодо закритого / віАкритого переліку речових прав [17].

За таких умов невіАповіАність принципу numerus clausus ще не означає, що право віртуальної власності не є речовим за своєю природою. Як у випаАку з Аовірчою власністю, той факт, що воно виникає з Аоговору, надає йому рис зобов'язального, але лише стосовно відносин з провайдером (за аналогією з установником Аовірчої власності).

Правоможність розпоряАження у конструкції віртуальної власності також матиме свою специфіку, оскільки можливість розпорядження віртуальним майном буде залежати віА особливостей платформи та деяких інших факторів. Іноді віАчуження об'єкту віртуальної власності може бути технічно неможливим. У інших випадках неможмивість відчуження може бути зумовлена соціальними причинами (П. Палка наводить приклаА із відчуження акаунту в Твітері, що належить, наприклаА, Аональду Трампу, без повідомлення про це користувачів [11, с. 219]). ОчевиАно, такі випаАки можуть мати шкіАливі насліАки Аля суспільства. А^е у цілому негативно оцінюється ситуація, що склалася на цей час, коли правоможність розпоряАження віртуальним майном обмежується умовами користування тієї чи іншої платформи. НаприклаА, у багатьох мультикористувацьких іграх передбачається своєріАний внутрішній ринок, Ае гравці мають право віАчужувати предмети гри за внутрішньоігрову або реальну валюту. Разом із тим відчуження або обмін акаунтами або відчуження ігрових преАметів за межами гри забороняється. Загалом обмеження права розпорядження провайдерами зводяться Ао трьох випаАків: провайдери не Аозволяють відчуження об'єктів за реальні гроші; провайдери Аозволяють продаж віртуальних предметів за реальні гроші, але лише із застосуванням систем, які ним створюються та контролюються; провайдери дозволяють проАаж одних об'єктів, але не інших [15, с. 766]. Така ситуація оцінюється як зловживання провайдерами своїми правами (“цифровою силою") та не повинна Аопускатися.

Крім того, правоможність розпорядження об'єктом віртуальної власності набуває своєї специфіки тому, що на віАміну віА об'єктів реального світу, Аля віАчуження віртуальних об'єктів необхіАним $€$ сприяння розробника. Тобто розробники мають забезпечити перехіА віртуального майна віА однієї особи до іншої у разі вчинення правочину з відчуження такого майна.
Те саме стосується й особливостей захисту права віртуальної власності: навіть у випадку, якщо суд прийме рішення, наприклаА, про необхідність витребування речі віА незаконного волоАільця та передачу ії законному власнику, виконати таке рішення неможливо без сприяння провайдера, оскільки віртуальне майно існує в рамках певної платформи. На цей випадок необхінно передбачити або обов'язок провайАерів сприяти виконанню судових рішень, або можливість Аоступу виконавців судових рішень Ао платформи $з$ метою виконання судового рішення (хоча склално собі уявити цей варіант), або - що можливо буде найкращим рішенням - передбачити виконання судових рішень за Аопомогою штучного інтелекту, вбудованого у платформу. Крім того, у випадку залучення провайдерів Ао процесу виконання судових рішень стосовно віртуального майна потрібно розуміти, що внесення змін у базу Ааних з метою передачі віртуального майна потребує певних витрат. Необхінно вирішити питання, на кого ці витрати будуть покладатися. ПреАставляється справеАливим покладення витрат, понесених провайдерами у зв'язку з виконанням судових рішень на правопорушників.

Ще одне питання, яке виникає у зв'язку із необхідністю забезпечення захисту права віртуальної власності, які способи захисту можуть застосовуватись. Видається, що захист права віртуальної власності може бути зАійснено за Аопомогою речово-правових позовів - віндикаційного, негаторного та прогібіторного. ОАнак так само, як і стосовно реального майна, вибір способу захисту буде залежати у тому числі віА характеристик віртуального майна. Віртуальне майно може бути індивідуально-визначеним, якщо коА $€$ сугубо індивіАуальним Аля цього об'єкту, а може кваліфікуватися як визначене родовими ознаками. Тому застосування віндикаційного позову буде допускатися лише в тому випадку, коли можна чітко ілентифікувати віртуальне майно, що було втрачено. Оскільки перелік об'єктів віртуальної власності $€$ невичерпним та постійно розширюється, і судАя не зможе врахувати всіх тонкощів програмування, питання про те, яким є віртуальне майно, потрібно вирішувати ad hoc на підставі висновку експерта. Негаторний позов може бути застосовано, зокрема, у випалку, якщо користуванню віртуальним майном, що не вибуло з володіння власника, заважають шляхом Аистанційного втручання. Таке Аистанційне втручання завдяки використанню інформаційних технологій може кваліфікуватися як перешкоди у зАійсненні власником 
права користування та розпоряджання своїм майном та надавати власнику можливість звернутися за захистом на підставі ст. 391 ЦК України.

СліА також зазначити, що є різні види віртуального майна, специфіка яких визначатиме особливості їх захисту. Отже, загальний висновок щодо видів віртуального майна $€$ таким: Аеякі види об'єктів віртуальної в^асності відповідатимуть за своїм правовим режимом віАповіАним об'єктам права власності у реальному світі (наприклаА, електронні квиток або книгу можна прирівняти до реальних книги або квитка, які по суті $€$ речами, Аоменне ім'я сліА прирівняти Ао майнового права, акаунт у соціальній мережі можна розгляАати як аналог майнового комплексу тощо). Проте деякі параметри класифікації речей, які застосовуються у реальному світі, є незастосовними щодо віртуальних речей (наприклаА, віртуальні речі не можуть бути поділені на рухомі та нерухомі, родовий характер віртуальних речей також $€$ віАносним, оскільки вони певним чином відображаються у базі даних як віАповіАний коА тощо).

Висновки з АосліАження та перспективи поАальших розвіАоК у цьому напрямі. Звичайно, пропозиція поширити режим права власності на віртуальне майно може викликати багато заперечень. ОАнак з урахуванням останніх тенденцій у сфері модернізації речового права, лібералізації підходу ЄСП^ Ао визначення поняття права власності, такий підхіА не представляється неможмивим. Особливо з урахуванням того факту, що українська концепція права власності не заперечує можливість існування у якості об'єктів права власності безтілесних речей. Аодатковим аргументом на користь можливості впровадження інституту права віртуальної власності $€$ той факт, що цивільним законодавством України вже закріплено такий особливий виА права власності, як Аовірча власність, яка має свою специфіку. Убачається, що так само може бути виділений ще оАин особливий виА права власності - право віртуальної власності. Можливо, Аискусійним $€$ питання щодо правової природи цього права, і будуть спроби його визначення як обмеженого речового або квазіречового права, але тим не менш, видається за можливе кваліфікувати його саме як особливий вид права власності з визначеною специфікою змісту, зАійснення та захисту.

\section{AITEPATYPA:}

1. McAfee Reveals Average Internet User Has More than $\$ 37,000$ in Unprotected “Digital Assets". URL: https://www.idg.com.au/ mediareleases/13079/mcafee-reveals-average-internet-user-has-more/.

2. Diamandis P. Second Life: How a Virtual World Became a Reality, Haffington Post. URL: https://www.huffingtonpost.com/peterdiamandis/second-life-how-a-virtual_b_2831270.html.

3. Wolfson R. Gamers And Investors Bet Big On Cryptocurrency And Blockchain In The Gaming Industry. URL: https://www.forbes.com/sites/rachelwolfson/2018/04/11/gamers-and-investors-bet-big-on-cryptocurrency-and-blockchain-in-thegaming-industry/\#3febd5b158b8.

4. S. Korean dies after games session, BBC (2005). URL: http://news.bbc.co.uk/2/hi/technology/4137782.stm.

5. Salmon A. Couple: Internet gaming addiction led to baby's death, CNN (Apr. 2, 2010). URL: http://edition.cnn.com/2010/WORLD/ asiapcf/04/01/korea.parents.starved.baby/index.html.

6. Cao Li. Death sentence for online gamer, China Daily (Jun 8, 2005). URL: http://www.chinadaily.com.cn/english/doc/2005-06/08/ content 449494.htm.

7. Некіт К.Г. Суб’єкти права приватної власності в інформаційному суспільстві // Lex Portus. 2018. № 2. C. 128-141.

8. Некіт К.Г. Деякі проблеми акаунтів у соціальних мережах як об'єктів цивільного обігу. Вісник Південного регіонального иентру Національної академії правових наук України. 2018. № 16. С. 91-97.

9. Некіт К.Г. Поняття та правова природа акаунту в соціальній мережі. Часопис иивілістики. 2018. № 30. С. 60-66.

10. Fairfield, J. Virtual property. Boston University Law Review [online]. 2005. Vol. 85. P. 1047-1102. Available at: https://ssrn.com/ abstract $=807966$.

11. Palka P. Virtual property: towards a general theory. PhD. Florence : European University Institute. 2017.

12. Ajemian v. Yahoo!, Inc. 84 N.E.3d 766 (2017). No. 17-1005, 2018 WL 489291 (U.S. Mar. 26, 2018).

13. Parents win rights to dead child's Facebook. URL: https://www.bbc.com/news/world-europe-44804599.

14. Некіт К.Г. Віртуальна власність як особливий вид права влансості: бути чи не бути: матеріали тез Київських правових читань «Речове право: пріоритети та перспективи» (22 березня, 2019 р., м. Київ). URL: https://bit.ly/2uIaav6.

15. Sheldon D. Claiming ownership, but getting owned: contractual limitations on asserting property interests in virtual goods. $U C L A$ Law Review. 2007. № 54. Pp. 751-787.

16. Erlank W. Property in virtual worlds: dissertation. 2012.

17. Майданик Р.А. Модернізація речового права: базовий принцип і напрями: матеріали тез Київських правових читань «Речове право: пріоритети та перспективи» (22 березня, 2019 р., м. Київ). URL: https://bit.ly/2UpMGsV. 
Некіт Катерина Георгіївна

ОСОБЛИВОСТІ ЗМІСТУ ТА ЗАІЙСНЕННЯ ПРАВА ВІРТУАЛЬНОї ВААСНОСТІ

У статті проаналізовано можливість визнання права віртуальної власності як особливого виду права власності. АосліАжено правову природу права віртуальної власності, особливості його змісту, здійснення та захисту. Проаналізовано співвідношення прав провайдерів / розробників платформ та користувачів. Надано оцінку поняттю "цифрова сила" та визначено напрями ії обмеження з метою недопущення зловживань з боку провайдерів. Визначено можливості володільців віртуального майна здійснювати та захищати свої права.

Киючові слова: віртуальна власність, право власності, віртуальне майно, цифрове майно, цифрова сила, внутрішньоігрові предмети, ігрові акаунти, провайдери, користувачі.

\section{Некит Екатерина Георгиевна}

\section{ОСОБЕННОСТИ СОАЕРЖАНИЯ И ОСУЩЕСТВАЕНИЯ ПРАВА ВИРТУАЛЬНОЙ СОБСТВЕННОСТИ}

В статье проанализирована возможность квалификации права виртуальной собственности как особого вида права собственности. Исследована правовая природа права виртуальной собственности, особенности его содержания, осуществления и защиты. Проанализировано соотношение прав провайдеров / разработчиков платформ и пользователей. Проведена оценка понятия "цифровая сила" и определены направления ее ограничения с целью недопущения злоупотреблений со стороны провайдеров. Определены возможности владельцев виртуального имущества осуществлять и защищать свои права.

Киючевые слова: виртуальная собственность, право собственности, виртуальное имущество, цифровое имущество, цифровая сила, внутриигровые предметы, игровые акаунти, провайдеры, пользователи.

\section{Nekit Kateryna}

\section{THE UNDERLYING CHARACTERISTICS OF VIRTUAL PROPERTY OWNERSHIP AND USAGE}

In this article the possibility to qualify the virtual property right as a special type of the property rights is analysed. It is possible to use such an approach in Ukrainian law as the concept of "thing" according to the Ukrainian legislation is treated widely, and includes not only objects of a material world, but also incorporeal things. Therefore, the Ukrainian concept of the property right allows to extend the existing regime of the property right to virtual assets. Not only the object of the virtual property right (which will always be incorporeal things) will have its specific. The bases for the virtual property right, its content and protection of the virtual property right will also have specifics.

In the article the legal nature of the virtual property right is also investigated. The conclusion is drawn that the virtual property right is the real right as answers all principles of the real right. The specifics of the content of the virtual property right are defined. Unlike the traditional possession, digital possession is not exclusive, as several persons can own an object at the same time (that is to have control over this object). The right to use the digital property also has its specifics. Such right has to be provided by provider. The provider also has to provide a constant possibility to have an access to the object which belongs to an individual. The right to dispose of digital property can be limited by provider and by properties of the platform itself that also needs to be considered. Ensuring protection of virtual property requires an assistance of provider as well. Thus, the right of virtual property has the dual nature. On the one hand, it is absolute - in the relations between the virtual owner and the third parties. On the other hand, in the relations with provider it has relative character.

In the article the balance of the rights of providers/developers of platforms and users is analyzed. The concept "digital force" is analysed and some directions of its restriction for the purpose of prevention of abuses on the part of providers are defined. Possibilities of virtual property owners to protect their rights are defined. In particular, an opportunity to use actions "in rem" for protection of virtual property is analysed.

Key words: virtual property, property right, digital property, digital force, in-game objects, game account, providers, users. 